\title{
Reflection, The National Board Certification Process, and Its Potential Impact on National Board Certified Teachers and their Practice
}

\section{Kathy Unrath}

"National Board Certification is simply the most intense and influential personal development activity available for a teacher. The NBPTS recognizes that teaching is an art and that to grow as artists, teachers need opportunities to ponder, look and listen" Jim Benz, (Benz, 1997)

The National Board for Professional Teaching Standards acknowledges that (Benz, 1997)reflection is an act that few teachers experience. According to the National Board Certification Portfolio Instructions: "Teachers generally have little practice in . . description, analysis, and reflection - it is not a part of the daily practice of teaching. Thinking analytically about teaching is complicated because teaching itself is complicated" (Standards, 1998). And yet, many believe that reflection leads to better action (D. Schon, 1983) and that reflective teachers are more effective teachers (Berliner, 1992). David Berliner (1992), whose research has focused on characteristics of expert teachers has found that "new teachers ... are less likely to be adequate teachers than those who have some reflected-on experiences under their belt" (p. 51). National Board Certified teachers have both garnered at least three years of experience in the field and completed the same structured portfolio building process that facilitated sustained reflection. Inquiring into their experiences can shed light onto the positive outcomes of becoming a reflective practitioner.

Candidates for National Board Certification participate in a rigorous yearlong process that affords them the opportunity to closely scrutinize their teaching practice. During the creation of their portfolios, the candidates choose artifacts that document their teaching prowess and write extensive commentaries, analyses, and interpretations about 
their work with students in their classrooms and beyond. The portfolio process is developed around a highly structured set of entries that allow the teachers the opportunity to present their actual classroom practice over a period of time. Reflection is imbedded in each entry prompt.

It is my contention that the process of the portfolio production and its attendant careful analysis and reflection effect a powerful change in the future practices of National Board Certified teachers. I am interested in understanding how this reflective process has changed these teachers and to what extent these teachers have become more reflective.

National Board Certification's recent history began with the publication by The Carnegie Task Force on Teaching as a Profession of A Nation Prepared Teachers for the $\underline{21}$ Sentury (Carnegie Task Force on Teaching as a Profession, 1986). This call for reform of our national educational system offered solutions to a perceived educational crisis. The report indicated that the key to success lies in creating a profession of welleducated teachers prepared to assume new powers and responsibilities to redesign schools for the future. Stakeholders were realizing that teachers of quality and the means of access to student achievement were learning environments conducive to student and teacher growth and achievement (Haas, 1997). In response to this challenge the National Board for Professional Teaching Standards (NBPTS) was established in 1987. The NBPTS, a private, non-profit body funded originally with five million dollars of Carnegie Corporation money over a five-year period, seeks to strengthen the profession of teaching and thereby raise the quality of education. The Board's mission is to establish high and rigorous standards for what accomplished teachers should know and be able to do; to develop and operate a national, voluntary system to assess and certify teachers who meet 
these standards; and to advance related educational reforms for the purpose of improving student learning in America (National Board for Professional Teaching Standards, 2000). The National Board for Professional Teaching Standards published a policy statement that set forth the board's conceptualization of standards for best practices entitled What Teachers Should Know and Be Able to Do. This document lists five core propositions:

1. Teachers are committed to students and their learning.

2. Teachers know the subjects they teach and how to teach those subjects to students.

3. Teachers are responsible for managing and monitoring student learning.

4. Teachers think systematically about their practice and learn from experiences.

5. Teachers are members of learning communities (Standards, 2000).

This study proposes to gather data related to the experiences of National Board Certified art teachers in order to understand how the development of the certification portfolio and its attendant requirements of daily reflection affect the quality of the teachers' practice.

The National Board Certification methodology presents an opportunity for teachers to implement meaningful change and improvement with far-reaching impact for the profession as a whole. This process stimulates a personal, reflective inquiry into a teacher' own practice. It is a professional development experience with potential for the advancement of learning for both teachers and students. Thinking, acting, reflecting, all of which are evident in the National Board Certification process, is found in this structured model for developing reflective practitioners. 
Professional teaching portfolio development provides the potential for both reflection-in-action and reflection-on-action. It provides a directed rationale for reflective thinking. The National Board Certification portfolio contains the elements that compel the candidates to reflect in a profound way about what they know and what they do.

\section{Statement of the Problem}

National Board Certified Art teachers have successfully completed a rigorous assessment of their practice and are therefore assumed to exemplify the five core values in their teaching practice. They have all been through the same structured certification experience. I believe that through examining this unique population we can learn a lot about the quality of this professional development exercise, the power of building professional teaching portfolios, and the lasting impact of becoming reflective practitioners.

The population of National Board Certified Art teachers will be surveyed to determine their perceived reflectivity level before and after undergoing the certification process. I will also seek to discover which components of the structured portfolio had the greatest impact on their ability to reflect and improve their teaching performance. For my

study an overriding main research question and several supportive sub-questions direct my work.

In what ways has the act of reflection, through the creation of the National Board Certification portfolio, effected, changed or enhanced the practice of National Board Certified Art Teachers? 
Sub-questions:

I will survey a sample of 100 of the current (2001) population of 305 National Board Certified Art Teachers with a Certificate in Early Adolescence through Young Adulthood Art to more specifically discover the answers to five additional queries:

1. To what extent did National Board Certified Art teachers reflect on their practice before undergoing the certification process?

2. How does the development of the NBCT portfolio facilitate reflection?

3. Which parts of the portfolio process had the greatest subsequent impact on changing your practice?

4. What aspects of your practice have been changed as a result of successfully completing the process of National Board Certification?

5. To what extent do you now perceive yourself to be a reflective practitioner? This study can provide insight into the importance of the reflective act as a tool for teacher efficacy and the value of the professional teaching portfolio as a structure that provides the opportunity for reflection to take place. It can also describe the extent to which master teachers, the population of National Board Certified teachers, think reflectively about their teaching both before and after creating the certification portfolio. It can demonstrate the important ramifications of self-study as a professional development device for teachers who do not necessarily choose to participate in National Board Certification by highlighting the most meaningful aspects of the certification portfolio. 
Four foundational concepts will guide this study: the reflective practitioner as described by Dewey and Schon, reflection as a part of the teaching and learning process, the professional teaching portfolio as a structure for reflective thinking, and the process of National Board Certification as defined by The National Board for Professional Teaching Standards.

\section{Reflection}

We must first understand what reflection is and how teachers reflect on and about the act of teaching. Reflection is defined in Merriam-Webster's Collegiate Dictionary (2001) as “consideration of some subject matter, idea, or purpose." Reflection can also be described as deep thinking, mindfulness, thoughtfulness, or as Dewey (1933) described, a "dialogue of thinking and doing". Teachers carry on this kind of dialogue within themselves each day as they reflect on their practice.

Many educational theorists have wrestled with the concept of deep sustained thinking and its relationship to teaching and learning. Some theorists, Dewey (1933), Habermas (1971), and Schon $(1983,1987)$ attempted to define reflection and the process of reflective thinking. Other theorists, King and Kitchener (1994) and Van Manen (1977), considered the stages of reflection. Experiential learning theorists such as Kolb (1984) sought to delineate the cycle of learning with reflection on experience being an important component.

Dewey (1933) was a pioneer in the development of the idea that we make meaning of our world through reflective thought. Nearly a half-century since his death, Dewey's writing is still valid; he states that reflection is purposeful and it has outcomes. Dewey separates thinking into separate categories, the most significant of which is 
reflective thinking, a significant component of educational terminology. What separates reflective thinking from other forms of thought is the two-phase process that defines it.

First, there must exist a state of doubt; some form of problem or conundrum must present itself. Second, there must exist an intentional act in the attempt to resolve the state of doubt.

In 1983, Donald Schon introduced the concept of reflective practice as a process for refining one's craft or artistry within a specific profession As defined by Schon, reflective practice involves thoughtfully considering one's own experiences in applying knowledge to practice (1987). Schon (1983) refers to two main processes of reflection in professional practice - reflection-in-action and reflection-on-action. Schon's ideas about reflection-in-and-on-action defined a new paradigm for thinking about the reflective act.

Both Dewey and Schon explain that when one reflects-in-action, reflection begins spontaneously out of either surprise or doubt about what is happening. The teacher stops, reflects on the problem in the midst of the action, states the problem, and then acts. It is an on-the-spot restructuring of the process of teaching based upon an instantaneous re-evaluation of past experiences. It is an intuitive act of faith on the part of the teacher that change and action are needed. And it is a deliberate, thoughtful diagnosis of a problem, doubt, and surprise, accompanied by a prescriptive act. The teacher revisits experiences and knowledge to reformulate a new path (Dewey, 1933; D. Schon, 1983).

\section{Reflection and Professional Development}

Reflection can be structured in several different ways with the outcome remaining the professional development of the practitioner. When teachers reflect on what they know and do, they are honoring their own knowledge and practice. Reflective practice is 
steeped into today's thinking about assessment, which includes portfolio creation and action research. Reflection can be seen as a tool for self-development and portfolio development provide structures for inquiry into practice. The framework for the production of professional portfolios supports the reflective act as portfolios provide a vessel for recording and documenting a practice. Schon (1995) explains that we all have the capacity of reflecting on what we know as revealed by what we do. And we also have the ability to reflect-in-action to generate new knowing.

Writing provides evidence of our reflective thinking and professional development. The act of writing our reflected thoughts gives them power, and writing simultaneously empowers the author. When we write with a purpose we are recording our thoughts. Schon (1983) indicates that writing makes thinking a "mindful act", and thus it can guide subsequent thought. When one writes reflections in a deliberate purposeful manner we are rethinking our thinking and therefore recognizing and honoring the reflective process.

\section{Professional Portfolios and Reflection}

The portfolio, another form of practice accountability, is complementary to the reflective journal that may be kept during action research. The process of producing a portfolio is also a form of research into practice. According to Shulman (1998) a portfolio is a "theoretical act" (p. 24). When you make a decision about which artifacts become reasonable portfolio entries, you are confirming and describing your personal teaching theory (Lyons, 1998). Each time a teacher makes a decision about which artifacts to include, he or she must reflect on which practices worked well and why (Ferrarro, 2000). 
Together with reflective writing portfolios tend to include other documents that summarize and interrelate the content, which may include such diverse items as graphic materials, photos, video, stories, or poetry.

\section{The National Board Certification Portfolio and Reflection}

Portfolio development is the cornerstone of the National Board Certification process. These candidates embark on a yearlong journey of reflection and discovery about teaching and learning. The candidate begins by creating a picture of professional life as the teacher encounters the certification portfolio process. One benefit of reflective practice for teachers is deeper understanding of their own teaching styles. The process of National Board Certification offers the opportunity to think deeply about not only teaching as evidenced by a portfolio that represents a tangible portrait of individual teaching over time but also as inspired by the more illusory portrait of reflective thought. Through the portfolio construction teachers gain the unexpected benefit of careful deliberation; they metacognitively process their teaching choices to assemble a meaningful record of their lives as teachers. The development of the certification portfolio is a process of deep reflection.

\section{References}

Benz, J. (1997). Measuring up: A personal journey through national board certification in art. Art Education, 50(5), 20-24,49-50.

Berliner, D. (Ed.). (1992). Exemplary performances: Studies of expertise in teaching. Reston, VA: The National Art Education Association.

Carnegie Task Force on Teaching as a Profession. (1986). A nation prepared: Teachers for the 21st Century: The report of the task force on teaching as a profession. New York: Carnegie Forum on Education and the Economy. 
Dewey, J. (1933). How we think: A restatement of the relationship of reflective thinking to the educative process. Boston: Heath.

Ferrarro, J. (2000). Reflective practice and professional development, from http://www.ericsp.org/pages/digests/reflective practice.html

Haas, F. (1997). Professional educator's licensure: The key to quality public schools. Retrieved September 14, 2001, from http://www.ed.gov/databases/ERIC Digests/ed1997-12

Habermas, J. (1971). Knowledge and human interests. London: Heineman.

King, P., \& Kitchener, K. (1994). Developing reflective judgement. San Francisco: Jossey-Bass.

Kolb, D. (1984). Experiential learning as the science of learning and development. Englewood Cliffs, New Jersey: Prentice Hall.

Lyons, N. (1998). Constructing narratives for understanding: Using portfolio interviews to scaffold teacher reflection. In N. Lyons (Ed.), With portfolio in hand Validating the new teacher professionalism (pp. 103-119). New York: Teachers College Press.

National Board for Professional Teaching Standards. (2000). What every teacher should know (No. ED430969). Washington D.C.: NBPTS.

National Board for Professional Teaching Standards. (1998). Early adolescence to young adulthood art portfolio. Washington D.C.: NBPTS.

Schon, D. (1983). The reflective practitioner. New York: Basic Books.

Schon, D. (1987). Educating the reflective practitioner. San Francisco: Jossey-Bass.

Schon, D. (1995). The new scholarship requires a new epistomology. Change, 27(November 21, 1995), 26-29.

Van Manen, M. (1977). Linking ways of knowing ways of being. Curriculum Inquiry, 6, 205-208. 